\title{
Some Endocrine Aspects of Precocious Sexual Maturation in the Amago Salmon Oncorhynchus rhodurus
}

\author{
Hiroshi UEDA*1, Yoshitaka NAGAHAMA*1, Fumio TASHIRo*2, \\ and Laurence W. CRIM*3 \\ (Accepted August 11, 1982)
}

\begin{abstract}
Changes in plasma androgen and gonadotropin (GTH) levels were correlated with changes in morphology of testes and pituitaries during precocious sexual maturation in the male amago salmon Oncorhynchus rhodurus parr. Although testicular development in precocious male parr began in early summer (June), dramatic increases in gonadosomatic indices occurred during the month of September. Active spermiation began in early October and continued into early November. Plasma androgen levels began to increase sharply in late August, coinciding with the onset of rapid testicular development. High circulating levels of androgen $(15-18 \mathrm{ng} / \mathrm{ml})$ were maintained during September, followed by a distinct drop in early October. Plasma GTH levels were relatively low during the major part of the spermatogenesis period and increased during the spawning period, followed by a sharp decline in spent males from mid-November.

There were two types of pituitary cells, globular cells and vesicular cells, which were found to be closely associated with testicular development. The globular cells were characterized by having a few large globular inclusions as well as numerous fine granules. These cells increased remarkably in number during the active spermiation period, coincident with the rise in plasma GTH levels, suggesting that the globular cells are the major source of GTH. The chromophobic vesicular cells appeared most active during the later stage of testicular development. It is concluded from these observations that pituitary GTH plays a major role in precocious sexual maturation of the male amago salmon parr.' This action of GTH may be mediated by the steroidogenic tissue of the testes.
\end{abstract}

It has been known that the majority of males (depending upon the stock) of the Atlantic salmon Salmo salar become sexually mature as parr in the second year of their lives. ${ }^{1,2)}$ Some recent studies on the Atlantic salmon have dealt with the endocrine control of this phenomenon. ${ }^{3-5)}$

Amago salmon Oncorhynchus rhodurus has a restricted distribution in the coastal sea and rivers of the western Pacific side of the mainland of Japan. Under hatchery conditions in Gifu Prefecture, amago salmon normally become sexually mature as two-year-old fish. However, some large males become precociously mature as one-year-old fish, easily recognized by their dark color. ${ }^{B)}$ Despite their interesting life history, no detailed physiological studies have been described in relation to the precocious early maturation. The present study was therefore conducted to correlate changes in plasma androgen and gonadotropin levels with changes in morphology of testes and pituitaries during precocious sexual maturation in the male amago salmon parr.

\section{Materials and Methods}

\section{Fish}

Amago salmon were reared in outdoor concrete ponds at the Gifu Prefectural Fisheries Experimental Station, supplied with a continuous flow of river water. The fish were fed on a commercially prepared dry diet twice daily. Six- to thirteenmonth-old males were sampled, 6-12 fish at a time, monthly or twice a month from September 1980 to August 1981, except in September and October, when weekly samples were taken. Samplings were always performed between $11: 00$ and 14:00 hours. After the animals were weighed and measured, the tail was severed and blood was collected in microhematocrit tubes, treated with heparin. After centrifugation, the plasma samples were frozen and

*1 Laboratory of Reproductive Biology, National Institute for Basic Biology, Okazaki 444, Japan （上畞 宏・長浜嘉孝: 基碳生物学研究所).

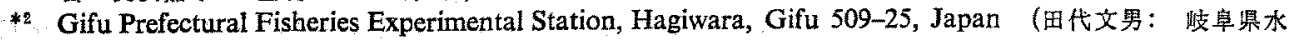
産試䲗場).

*8 Marine Sciences Research Laboratory, Memorial University of Newfoundland, St. John's, Newfoundland A1C 5\$7, Canada. 
stored at $-20^{\circ} \mathrm{C}$ in plastic microcentrifuge tubes until hormone analysis was performed. Testicular development was estimated by the gonadosomatic index (GSI; gonad weight/body weight multipled by 100).

\section{Light microscopy}

For ordinary light-microscope studies, samples of pituitaries were fixed in Bouin-Holland-sublimate. Serial sections of $5 \mu \mathrm{m}$ thickness were stained with Masson's trichrome. Pieces of testes were fixed in Bouin and stained with Mayer's hematoxyline-eosin. In addition, small pieces of testes and pituitaries were fixed with Karnovsky's glutaraldehyde-paraformaldehyde mixture in $0.2 \mathrm{M}$ cacodylate buffer ( $\mathrm{pH} 7.4$ ) for 1 day at room temperature, post-fixed in $1 \%$ osmium tetroxide in the same buffer for about 2 hours at room temperature. The tissues were dehydrated and embedded in low-viscosity epoxy. ${ }^{7}$ Thick sections of about $1 \mu \mathrm{m}$ were cut on a Sorvall MT-1 ultramicrotome and stained with methylene blueazure II, and examined under a light microscope.

\section{Radioimmunoassay ( $R I A)$}

Plasma gonadotropin concentrations were determined using a RIA technique specific for salmonid gonadotropin..$^{8,0)}$ The procedure was validated for amago salmon GTH by establishing parallelism for serial dilutions of several potent plasma samples obtained from ovulating females. Plasma androgen levels were measured by RIA according to the method of KaGAwA et al. ${ }^{10)}$ Rabbit anti-testosterone-11-hemiscuccinate-BSA serum were obtained from Teikokuzoki Pharm. Company, Tokyo. The anti-testosterone serum cross-reacts with testosterone, 11-ketotestosterone, androstenedione, dehydroepiandrosterone and estradiol-17 $\beta$ at 100 , $114,2.24,0.017$ and $0.009 \%$, respectively. The intra-assay coefficient of variation for the RIA of amago salmon plasma was $6.49 \%(n=10)$. The lower limit of detection was $20 \mathrm{pg} /$ tube.

\section{Statistics}

All data are expressed as mean \pm SEM. Differences were calculated by analysis of variance followed by Student-Newman-Keuls' multiple range test.

\section{Results}

\section{Testicular Development}

Changes in the gonadosomatic index (GSI) are shown in Fig. 1. In the immature male smolt, the GSI values were consistently low from June

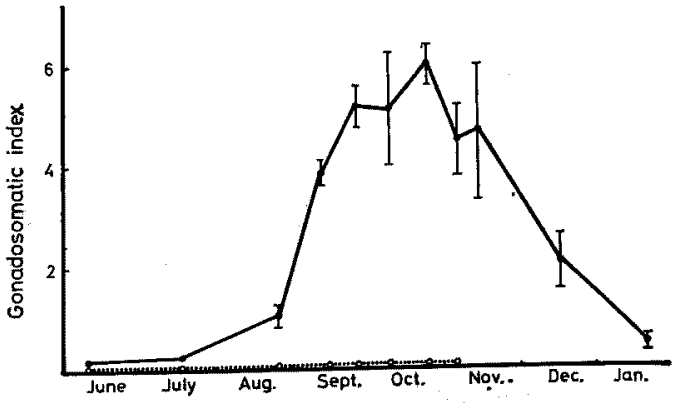

Fig. 1. Changes in the gonadosomatic index during precocious sexual maturation in male amago salmon. Precocious male parr (-0); immature male smolt $(\mathrm{O}-\mathrm{O})$. The vertical bars represent the mean $\pm S E M$.

through October; during this period the testes remained unchanged and consisted entirely of spermatogonia. In the precociously maturing male parr, the GSI values remained relatively low during the early and mid-summer months (June and July); the testes at these periods were composed mostly of spermatogonia along with a small number of spermatocytes (Plate IA). A sharp increase in the GSI occurred during September, with the increased formation of spermatozoa (Plate IB). High GSI values of 4-6 were maintained until early November, followed by a steady decrease by January. Active spermiation began in early October and continued into early November. During this time, the testicular lobules were generally filled with mature sperm (Plate IC), but some of the lobules contained smaller numbers of sperm, thus indicating that release of sperm was in progress or had occurred. At the later stages (December and January), Sertoli cells were hypertrophied and often contained degenerated sperm (Plate ID). Resorption of these sperm was completed by February.

\section{Changes in Plasma Androgen Levels}

A brief description of changes in plasma testosterone levels during parr-smolt transformation of amago salmon has been described elsewhere.") No significant difference in plasma androgen levels was observed between precocious males and immature males collected in June and July. Plasma androgen levels of precocious males were significantly $(\mathrm{p}<0.05)$ elevated in late August, and their maximum levels $(18.61 \pm 0.84 \mathrm{ng} / \mathrm{m} l)$ were reached by early October just prior to the peak of the GSI (Fig. 2). The levels then quickly decreased to reach a minimum in December. Immature males 


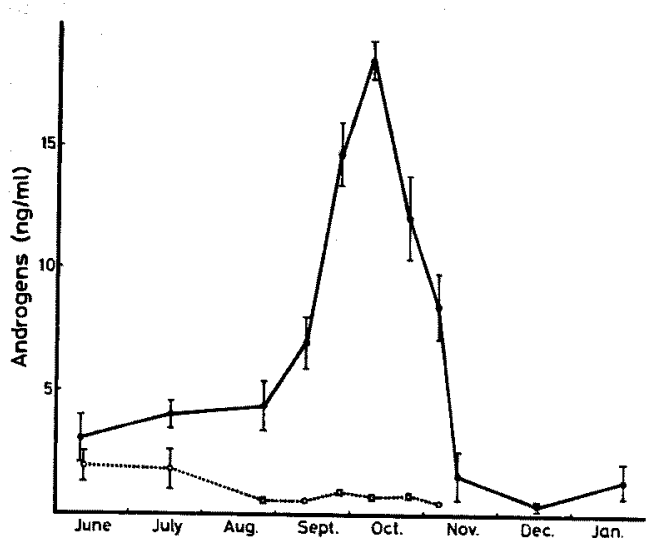

Fig. 2. Changes in plasma androgen levels during precocious sexual maturation in male amago salmon. Precocious male parr (๑-); immature male smolt $(\mathrm{O}--\mathrm{O})$. The vertical bars represent the mean $\pm S E M$.

showed consistently low plasma androgen levels throughout the sampling periods.

\section{Changes in Plasma GTH Levels}

Plasma GTH levels for precocious males and immature males are shown in Fig. 3. The hormone levels in precocious males remained consistently low in September and early October, although the values on September 12 were significantly higher than those of September 19 and $26(p<0.05)$. A significant $(\mathrm{p}<0.01)$ increase in plasma GTH occurred in precocious males collected on October 9 , and higher levels of $2-3 \mathrm{ng} / \mathrm{ml}$ were maintained until early November, followed by a sharp drop on November 14. Plasma GTH was consistently low in the immature male smolt including collections made in mid-October, the time of a significant increase in plasma $\mathrm{GTH}$ in precociously mature male parr.

\section{General Morphology of the Pituitary Glands}

The general morphology of the pituitary glands of the male amago salmon parr is similar to those described in other salmonid species. ${ }^{11)}$ The rostral pars distalis (RPD) is composed of prolactin (PRL) cells, adrenocorticotropic cells and nongranular stellate cells. The proximal pars distalis (PPD) is composed of four different kinds of granular cells. In June, acidophilic growth hormone (GH) cells appeared to be larger and more numerous in the precociously maturing male parr than in the sexually immature parr. Thyrotropic (TSH) cells, stained weakly with aniline blue, are located in an intermediate position between the RPD and

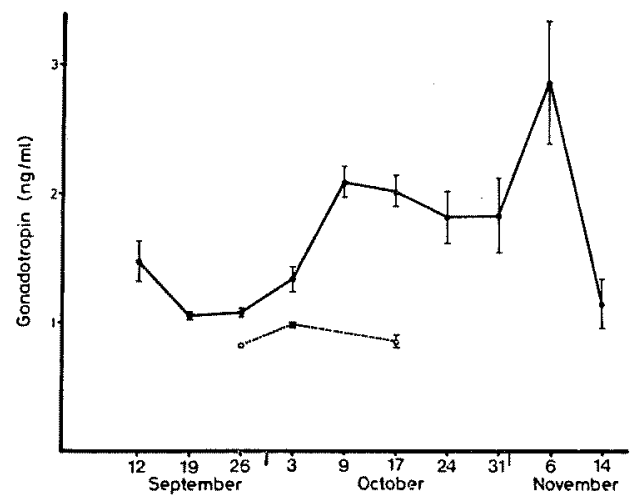

Fig. 3. Changes in plasma gonadotropin levels during precocious sexual maturation in male amago salmon. Precocious male parr (-); immature male smolt $(\mathrm{O}-\mathrm{O})$. The vertical bars represent the mean $\pm \mathrm{SEM}$.

PPD. These cells appeared less active in precociously mature male parr than in immature male smolts. In the present study, two types of cells in the PPD were found to be associated with testicular activity and were designated as "globular" and "vesicular" cells on the basis of the appearance of their cytoplasm. The globular cells are present in the ventral and central PPD. Their cytoplasm is filled with evenly dispersed fine granules and a few globular inclusions, both of which are strongly positive to aniline blue in Masson's trichrome stain. The vesicular cells which predominate in the central and dorsal regions of the PPD are large and almost colorless (chromophobic) with Masson's trichrome. In methylene blue-azure II stained sections, these cells are white in color containing many vesicular structures.

\section{Changes in Globular and Vesicular Cells During Precocious Maturation}

Light-microscope observations on the globular and vesicular cells during various stages of precocious sexual maturation were carried out on both paraffin and Spurr-embedded sections.

The pituitaries of precociously maturing males (six-month-old) killed in June already contained a small number of vesicular cells which showed a restricted distribution in the dorsal part of the PPD (Plate IIA). They were round or oval in shape and often had a round nucleus. At this stage no typical globular cells were found. During August to late September the pituitaries enlarged, especially the PPD. The vesicular cells increased in number and size (Plate IIB), and extended to the central part 
of the PPD; vacuolization was observed on rare occasions. The first appearance of typical globular cells was noted in the pituitaries of precocious male parr collected in mid-September; these cells appeared to first develop in the vicinity of the ventral expansion of the RPD. During the subsequent course of testicular development (late September to October), the globular cells displayed a pronounced increase in size and number; some globular cells were also found in the PRL follicles in the RPD. In late October, the globular cells showed increased accumulation of granules in their cytoplasm; the globular inclusions became more conspicuous (Plate IIC). In contrast, the vesicular cells appeared to reveal little or no change during the later stage of testicular development (late September to November).

In spent males collected in December, there was a marked decrease in the number of the vesicular cells. Although considerable numbers of globular cells were still present in the pituitaries at this stage, their affinity to aniline blue was much reduced (Plate IID). The most striking features of pituitaries of spent males collected in March was the almost complete disappearance of both globular cells and vesicular cells.

In the immature male smolts at the end of the first year of their life (October-December) the PPD consisted almost entirely of acidophils. Only a few basophils were present, most of them were putative TSH cells which were limited to the ventral PPD adjacent to the RPD. The vesicular cells were very few in number, occurring in the dorsal PPD (Plate IIE).

\section{Discussion}

The incidence of early maturation among salmonids has been shown to vary between species. ${ }^{2)}$ A very high incidence $(90-95 \%)$ of precocious maturity was observed in males of Atlantic salmon from both North Wales and Newfoundland populations. However, no cases of precocious females have been described. ${ }^{3,4)}$ About $50-60 \%$ of male parr of amago salmon become precociously mature as one-year-old fish ${ }^{12)}$; the spermatogenic process of these fish appears to be normal, since they can produce fertile sperm. By the following year some of these precocious male parr become sexually mature for a second time. The occurrence of precocious female amago salmon is also possible, since two precocious female parr were discovered during our 1981 samplings.
The GSI values of precocious male amago salmon parr were relatively low throughout the summer months, after which the values increased dramatically. A similar testicular development during precocious sexual maturation was described for the male Atlantic salmon parr., ${ }^{3,4)}$ In our study, spermiation began in early October and continued into November. During these periods, a relatively large amount of spermatozoa remained in the testicular lobules and sperm ducts. This may be due to the lack of precocious female parr under hatchery-reared conditions. However, a poor spermiation yield has also been reported in adult mature rainbow trout; only 5 to $20 \%$ of the spermatozoa present in the testis was collected by hand-stripping, the rest remaining in the testis and degenerating within a few months. ${ }^{13)}$

Very little is known about the endocrine control of spermatogenesis in teleost species. The administration of various androgens to intact or hypophysectomized fish can influence spermatogenesis either by enhancement or by inhibition. In the precocious male amago salmon, the levels of circulating androgens increased during rapid testicular development, followed by a sharp decline during spawning period. A recent study by HuNT et al. ${ }^{14)}$ showed that both testosterone and 11-ketotestosterone sharply decline in plasma of adult Atlantic salmon at the onset of spermiation. These results indicate the possible importance of androgens in the control of the later stages of spermatogenesis in these salmonid species. The present study does not allow us to determine which androgen, 11ketotestosterone or testosterone, was higher in precocious male amago salmon parr, since the antiserum used binds both androgens.

The concentration of plasma GTH remained low until late September when the GSI and plasma androgen levels were already nearly maximum, although precocious males collected in early September had relatively high GTH values. These results are in agreement with much previous work in male salmonids characterizing seasonal GTH fluctuations with the development of the testes and spawning. In general GTH remains low for the early phases of spermatogenesis but elevations in the plasma GTH levels are clearly related to the period of spermiation at spawning. ${ }^{\text {s.15) }}$ To date, all radioimmunoassay systems developed for measurement of GTH in salmonid plasma are thought to be relatively specific for determining a glycoprotein-rich gonadotropic hormone preparation which has been called maturational hormone. NG and 
IDLER $^{(a)}$ established that maturational hormone is responsible for steroidogenesis in the male and thus it seems reasonable to assume that the rise in GTH is directly related to increasing androgen production associated with the final stages of spermatogenesis and spermiation. It is a subject for future studies to define the role of GTH at the point of onset of spermatogenesis which has recently ${ }^{14}$, been correlated with very subtle fluctuations in plasma androgens.

The endocrine control of spermiation has not been well documented in teleosts. Gonadotropin can restore spermiation in hypophysectomized goldfish, ${ }^{18)}$ thus suggesting the involvement of GTH in inducing spermiation in this species. Our finding in amago salmon that plasma GTH is highest during spermiation is in agreement with the observations on other salmonid species, ${ }^{a, 8)}$ Although the precise mechanism underlying the action of GTH on spermiation is unknown, it is likely that GTH action is mediated by steroidogenic tissues; steroidogenesis may occur in at least two sites in the teleost testis, the interstitial (Leydig) cells and the Sertoli (lobule boundary) cells. ${ }^{17-19}$ It is possible that GTH interacts with these cells to stimulate the synthesis and secretion of steroids. In addition to their involvement in spermatogenesis, testicular steroids are believed to be involved in spermiation. However, conclusions as to the nature of active steroids and their origin are contradictory. It is significant to note in the present study that the concentration of plasma androgens began to fall sharply in early October at a time when the GSI and plasma GTH values were still high or increasing; it was a further 2 months before the plasma GTH values declined. Therefore, it is tempting to postulate that high plasma GTH during spermiation gives rise to enhanced testicular synthesis of steroids besides androgens. During the spermiation period of Atlantic salmon, plasma 11-ketotestosterone and testosterone fall markedly ${ }^{14}$ ) but at the moment 11-ketotestostrone has not been measured in amago salmon. In precocious male Atlantic salmon, plasma 11ketotestosterone was found to be much higher than testosterone and rose sharply at maturity and falling dramatically as the testes regressed.4,5) The involvement of progestogens in the regulation of spermiation may also be possible, since progesterone was found to be more potent than testosterone and methyltestosterone in inducing spermiation in hypophysectomized goldfish. ${ }^{20)}$ This hypothesis is further supported by our recent finding in amago salmon. Circulating levels of $17 \alpha, 20 \beta$-dihydroxy4-pregnen-3-one were low during the process of active spermatogenesis, but elevated sharply during spermiation. ${ }^{21)}$

The globular cells of the precocious male amago salmon contained numerous fine granules and a few large globular inclusions. These characteristics of globular cells have been described for the GTH cells of a number of teleost species, including salmonid species. ${ }^{22}$ ) Our recent immunocytochemical studies demonstrated that antiserum against chum salmon GTH locates in the globular cells of the precocious male amago salmon*. Therefore, it is likely that the globular cells are the major cellular source of GTH in the amago salmon pituitary.

In the present study, a marked increase in the number of globular cells occurred during the active phase of spermatogenesis, coincident with the rise in plasma GTH and androgen levels. A similar development of pituitary basophils in association with precocious maturity was previously reported in the male king salmon $O$. tschawytscha parr. ${ }^{23}$ ) In our study, no marked degranulation was observed in the globular cells at any stage during the spawning season. This observation is different from the situation in females where a marked degranulation occurs in the globular GTH cells at the time of final oocyte maturation and ovulation. ${ }^{11,24)}$ These apparent differences in the activity of globular GTH cells are consistent with earlier studies on salmonid species demonstrating that increases in plasma GTH levels were much greater in ovulating females than in spermiating males, ${ }^{98}$ ) Although maximum activity of the globular cells was evident during the active spermiation period, the cells were found to be present in the pars distalis continuously from September until February, after which they disappear completely. This observation is in accord with that of CrIM and Evans ${ }^{3)}$ on the precocious male Atlantic salmon parr in which pituitary GTH elevation lasted from October through March. There is also agreement between the observations of CRIM et al. ${ }^{263}$ showing that testosterone induces pituitary GTH accumulation and the present demonstration in the amago salmon of a strong correlation between the rise in plasma androgen and onset of the appearance and development of large numbers of globular cells in the PPD.

The pars distalis of the precocious male amago

* Ueda and Nagahama, unpublished. 
salmon contained a prominent cell type which was characterized by large amounts of vesicular structures, and therefore designated as the vesicular cell. Cells with similar features have been reported for some salmonid species (rainbow trout ${ }^{27,28)}$, Atlantic salmon ${ }^{28,30)}$, masu salmon $O$. masou, ${ }^{\text {(1) }}$ sockeye salmon $O$. nerka, ${ }^{32)}$ white-spotted char Salvelinus leucomaenis $\left.{ }^{24}\right)$. However, there is still controversy regarding the functional significance of this cell type. Some investigators have considered this cell type to represent different stages of secretory activity of a single $\mathrm{GTH}^{27-30)}$; no evidence of more than one type of GTH cell was found in these studies. In the sexually mature rainbow trout, ${ }^{287}$ the globular cells were considered to transform into vesicular cells after ovariectomy, followed by a remarkable elevation of plasma GTH, suggesting that the cisternal GTH cells are the activated form of the globular GTH cells.

In contrast, other investigators have considered these vesicular cells as a separate GTH cell. ${ }^{24,31-33)}$ In these studies two kinds of GTH cells were identified, each of which appears to have a separate gonadotropic function. In our study, the vesicular cells were first observed during the early stages of testicular development and appeared to be correlated with reproductive activity, particularly the later stages of spermatogenesis. Recently, TSH cells were identified in the amago salmon pituitary by immunocytochemical methods using anti-human $\beta$-TSH; these cells were present in the ventral PPD adjacent to the RPD, ${ }^{*}$ and appear to correspond to putative TSH cells identified by PUTTEN et al. ${ }^{28)}$ in their recent ultrastructural and immunocytochemical analysis of the rainbow trout pituitary. Our observations on amago salmon are consistent with the concept that the vesicular cells are involved in modulating gonadal activity and thus a possible source of GTH.

In conclusion, it is clear from the present study that precocious maturation in male amago salmon parr is related to an apparent activation of the pituitary (GTH)-testicular (steroids) axis. Furthermore, recent studies by DoDd et al. ${ }^{4)}$ and CRIM and PETER ${ }^{84)}$ suggest the possible involvement of the hypothalamus during early maturation in male Atlantic salmon parr. Other hormones such as growth hormone, thyrotropin and thyroid hormones which have been implicated in the process of parr-smolt transformation in salmonids $s^{8,85,36)}$ may exert indirect or direct effects on precocious maturation. Certainly these possibilities merit further studies for the adequate understanding of the endocrine control of precocious sexual maturation in salmonid fishes.

\section{Acknowledgements}

We thank Dr. G. Young for reading the manuscript, and Mr. S. ADACHI for his excellent technical assistance. This study was supported by a grant-in-aid for special project research on marine biological processes (No. 521906) from the Ministry of Education, Japan.

\section{References}

1) J. W. Jones: Proc. Roy. Soc. London, Ser. B, 128, 499-509 (1940).

2) J. E. THORPE: Scott. Fish. Bull., 42, 15-17 (1975).

3) L. W. CRIM and D. M. EvaNs: Can. J. Zool., 56, 1550-1555 (1978).

4) J. M. Dodd, P. A. C. Stuart-Kregor, J. P. Sumpter, L. W. Crim, and R. E. Peter: in "Comparative Endocrinology" (ed. by P.J. GAILlaRD and H.H. BoER), Elsevier/NorthHolland Biomedical Press, Amsterdam, 1978, pp. 101-104.

5) P. A. C. Stuart-Kregor, J. P. SUMPter, and J. M. DODD: J. Fish Biol., 18, 59-72 (1981).

6) Y. Nagahama, S. Adachi, F. Tashiro, and E. G. GraU: Aquaculture, 28, 81-90 (1982).

7) A. R. SPURR: J. Ultrastruct. Res., 26, 31-43 (1969).

8) L.W. Crim, R.K. Meyer, and E. M. Donaldson: Gen. Comp. Endocrinol., 21, 69-76 (1973).

9) L. W. Crim, E. G. Watts, and D. M. Evans: Gen. Comp. Endocrinol., 27, 67-70 (1975).

10) H. Kagawa, K. Takano, and Y. Nagahama: Cell Tiss. Res., 218, 315-329 (1981).

11) Y. Nagahama: Mem. Fac. Fish. Hokkaido Univ., 21, 1-63 (1973).

12) T. Номлон: Rep. Gifu Pref. Fish. Exp. St., 22, 1-103 (1977).

13) R. Brllard, B. Jalabert, and B. Breton: Ann. Biol. anim. Biochem. Biophys., 12, 19-32 (1972).

14) S.M.V. HuNT, T.H. Simpson, and R. S. Wright: J. Fish Biol., 20, 105-119 (1982).

15) R. Billakd, A. Fostier, C. WeIL, and B. Breton: Can. J Fish. Aquat. Sci., 39, 65-79 (1982).

16) T. B. NG and D. R. IDler: Gen. Comp. Endocrinol., 42, 25-38 (1980).

17) S.S. Guraya: Int. Rev. Cytol., 47, 99-136(1976).

18) W.S. HoAR and Y. NAGAHAMA: Ann. Biol. anim. Biochem. Biophys., 18, 893-898 (1978).

19) Y. Nagahama, H. Kagawa, and G. Young: Can. J. Fish. Aquat. Sci., 39, 56-64 (1982).

\footnotetext{
* Ueda and Nagahama, unpublished.
} 
20) R. BILLARD: IRCS, 4, 42 (1976).

21) H. Ueda, G. Young, L. W. Crim, A. Kambegawa. and Y. Nagahama: Gen. Comp. Endocrinol., (in press)

22) R. L. Holmes and J.N. Ball: The Pituitary Gland: A Comparative Account, 1st ed., Cambridge Univ. Press, London, 1974, pp. 1-397.

23) O. H. Robertson and B. C. WeXIER: J. Morph., 110, 171-185 (1962).

24) H. UEDA: Bull. Fac. Fish. Hokkaido Univ., 31, 1-15 (1980).

25) R. E. Peter: Gen. Comp. Endocrinol., 45, 294-305 (1981).

26) L. W. Crum, R. E. Peter, and R. Billard: Gen. Comp. Endocrinol., 44, 374-381 (1981).

27) J. Peute, H. J. Th. Goos, M. G. A. De BruYN, and P. G. W. J. VAN OORDT: Ann. Biol. anim. Biochem. Biophys., 18, $905-910$ (1978).

28) L. J. A. Van Putten, J. Peute, P. G. W. J. Van
Oordt, H.J. Th. Goos, and B. Breton: Cell Tiss. Res., 218, 439-448 (1981).

29) B. Ekengren, J. Peute, and G. Fridberg: Cell Tiss. Res., 191, 187-203 (1978).

30) K. LiNDAHL: Acta Zoot. (Stockh.), 61, 117-125 (1980).

31) H. UEDA and T. HirAshima: Annot. Zool. Japon,, 52, 114-124 (1979).

32) H. Cook and A. P. VAN Overbeeke: Z. Zellforsch. Mikrosk. Anat., 130, 338-350 (1972).

33) M. Olivereau: Gen. Comp. Endocrinol., 28, 8295 (1976).

34) L. W. Crim and R. E. Peter: Ann. Biol. anim. Biochem. Biophys., 18, 689-694 (1978).

35) L. C. Folmer and W. W. DickhoFf: Aquaculture, 21, 1-37 (1980).

36) G. A. Wedemeyer, R. L. Saunders, and W. C. Clarke: Mar. Fish. Rev., 42, 1-14 (1980). 


\section{Explanation of Plates I and II}

Plate I. Light-micrographs of testes of precocious male amago salmon parr. Spurr-embedded and methylene blue-azure II-stained preparations. A, testis of precocious male parr collected in June. The lobules contain many spermatogonia and a few spermatocytes $(\times 440)$. B, testis of precocious male parr collected in early September. The lobules contain a variety of germ cells including spermatocytes, spermatids and spermatozoa $(\times 440)$. C, testis of precocious male parr collected in late October. The lobules are filled with large amounts of mature sperm ( $\times 740$ ). D, testis of precocious male parr collected in December. The lobules contain small numbers of sperm. Note hypertrophied Sertoli cells containing degenerated sperm $(\times 740)$.

Plate II. Spurr-embedded $1 \mu \mathrm{m}$ sections of pituitaries of precocious male amago salmon parr and immature male smolts. Methylene blue-azure II staining. G, globular cell; V, vesicular cell. A, PPD of a precocious male parr collected in June $(\times 440)$. B, PPD of a precocious male parr collected in early September. Note the remarkable increase in size and number of the vesicular cells $(\times 440)$. C, PPD of a precocious male parr collected in mid-October. Both the globular and vesicular cells were present $(\times 2000)$. D, PPD of a precocious male parr (spent) collected in December. Only globular cells were present $(\times 1400)$. E, PPD of an immature male smolt collected in October. Only a few vesicular cells were observed $(\times 1400)$. 
Plate I

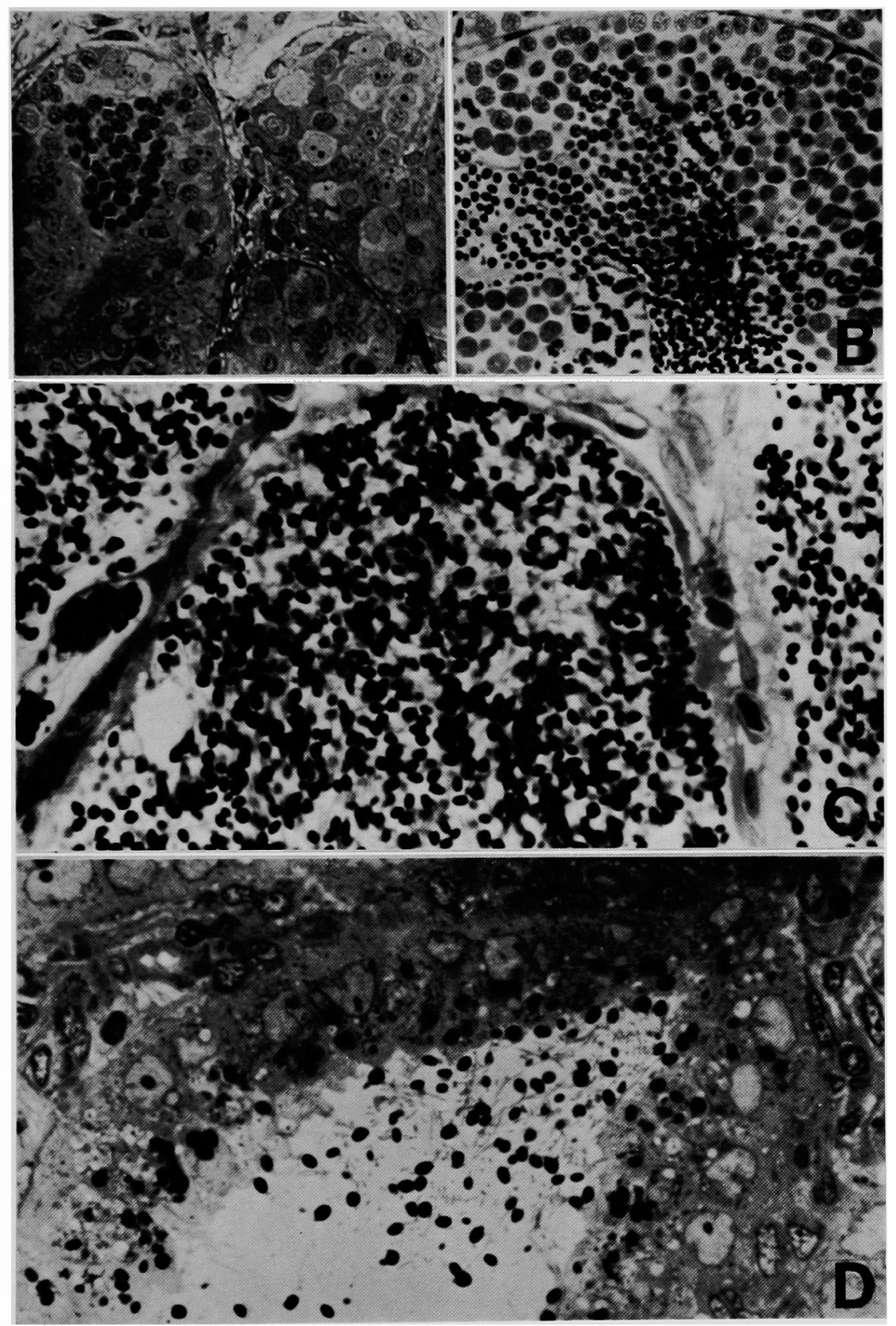


Plate II
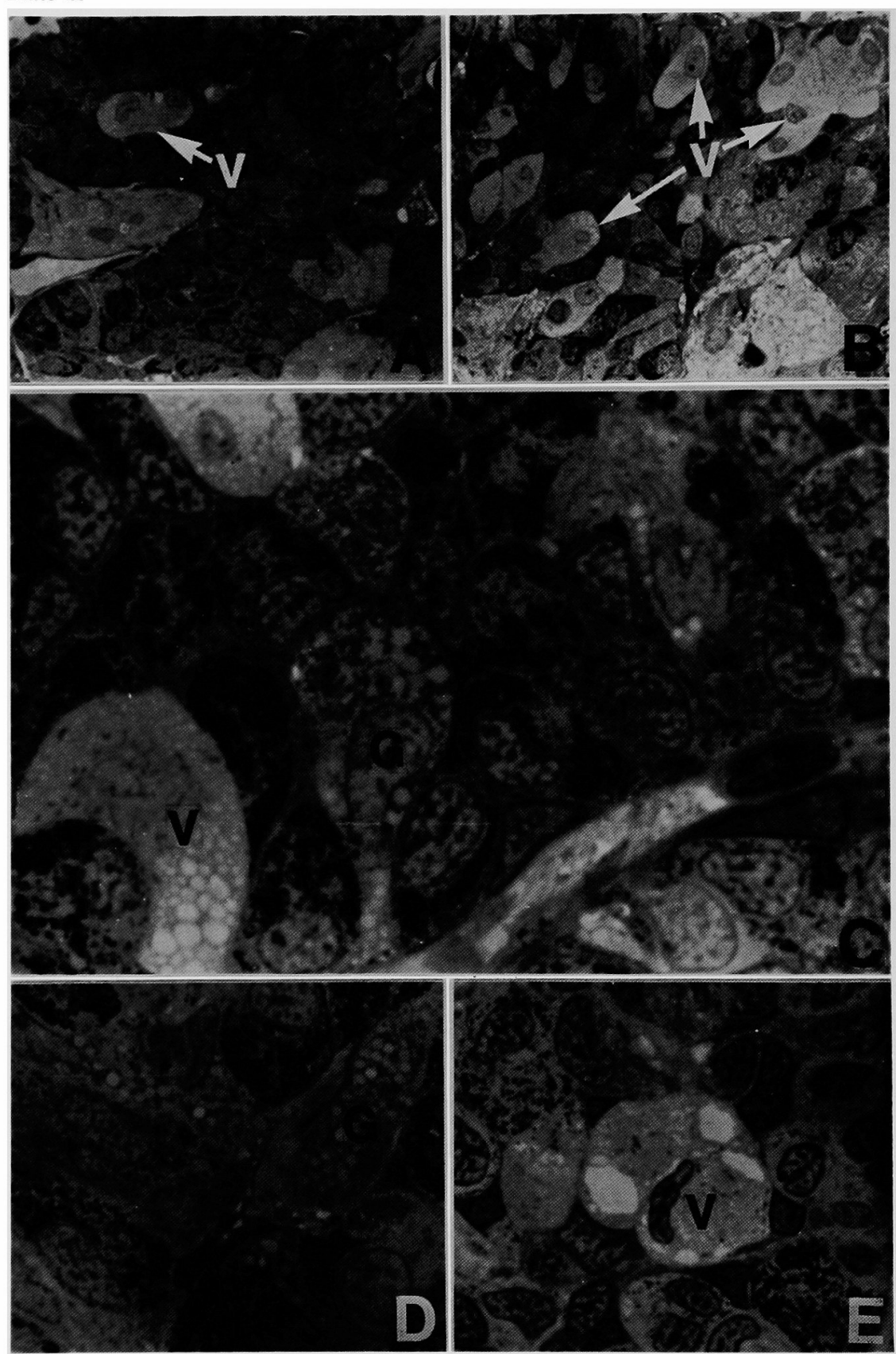